\title{
Milk and cow's meat allergy in a child: A clinical case
}

\section{Alergia ao leite e carne de vaca em idade pediátrica: Caso clínico}

Data de receção / Received in: 23/9/2020

Data de aceitação / Accepted for publication in: 21/12/2020

\author{
Rev Port Imunoalergologia 202I;29 (4):273-277 \\ Maria Luís Marques' (iD, Inês Falcão' (iD, Moisés Labrador-Horrillo² (iD, Helena Falcão' (iD, Leonor Cunha' (iD) \\ I Allergy and Clinical Immunology Department. Hospital Geral de Santo António, Centro Hospitalar Universitário do Porto, \\ Porto, Portugal \\ ${ }^{2}$ Sección de Alergia. Hospital Vall d’Hebron. Universitat Autònoma de Barcelona, Espanha
}

\section{ABSTRACT}

Allergy to bovine serum albumin is the main predictor of beef allergy associated with cow's milk proteins allergy. We report a case of a 3-year-old child with cow's milk proteins allergy since the age of 6 months who, after some ingestions of beef, developed episodes of irritability, urticaria and syncope. Specific IgE to beef, oral food challenge with medium rare cooked beef and specific lgE to bovine serum albumin were all positive, but an oral food challenge with well cooked beef was tolerated. Allergy to bovine serum albumin is not usually associated with severe reactions, since it is a thermolabile protein, however, the process of cooking meat may be insufficient to have an effect on the complex matrix of meat and associated serum albumins. The irregular pattern of the episodes and the previous diagnosis of cow's milk proteins allergy may act as confounding factors leading to a delayed diagnosis.

Keywords: Bovine serum albumin, cow's milk protein allergy, food allergy, meat allergy.

(C) 2021 Sociedade Portuguesa de Alergologia e Imunologia Clínica. Published by Publicações Ciência \& Vida. This is an open access article under the CC BY-NC-ND license (http://creativecommons.org/licenses/by-nc-nd/4.0/)

\section{RESUMO}

A alergia à albumina sérica bovina é o principal preditor de alergia à carne de vaca associada à alergia às proteínas do leite de vaca. Criança de 3 anos com alergia às proteínas do leite de vaca diagnosticada aos 6 meses que, após algumas ingestões de carne de vaca, desenvolveu episódios de irritabilidade, urticária e síncope. A lgE específica para 
carne de vaca, a prova de provocação oral com carne de vaca medianamente cozinhada e a lgE específica para a albumina sérica bovina foram positivas, porém a prova de provocação oral com carne de vaca bem cozinhada foi tolerada. A alergia à albumina sérica bovina geralmente não está associada a reações graves, dado tratar-se de uma proteína termolábil, contudo, o processo de cozedura da carne pode ser insuficiente para afetar a complexa matriz da carne e albuminas séricas associadas. O padrão irregular dos episódios e o diagnóstico prévio de alergia às proteínas do leite de vaca podem ser fatores confundidores levando ao diagnóstico tardio.

Palavras-chave: Alergia a carne, alergia a proteínas do leite de vaca, alergia alimentar, albumina sérica bovina

(c) 202I Sociedade Portuguesa de Alergologia e Imunologia Clínica. Publicado por Publicações Ciência \& Vida. Este é um artigo Open Access sob uma licença CC BY-NC-ND (http://creativecommons.org/licenses/by-nc-nd/4.0/)

\section{INTRODUCTION}

M eat allergy is becoming an increasingly recognized condition and a higher prevalence is seen in pediatric age compared to adults. In some case series meat allergy seems to represent $3-15 \%$ of all pediatric cases of food allergy ${ }^{1,2}$. The real prevalence of meat allergy in children with cow's milk protein allergy (CMPA) is difficult to estimate. Few studies address this question, generally small and with different study methods, possibly leading to overestimations on its true epidemiology ${ }^{3}$. Only two studies reported prevalence of meat allergy in CMPA based on oral food challenges (OFC), with study samples of 15 and 25 patients, and they found that the estimated prevalence of meat allergy is between $13 \%^{4}$ and $20 \%^{5}$, respectively.

When meat allergy is diagnosed during early childhood, the prognosis is usually good with clinical resolution during the first years of life ${ }^{1,3}$.

\section{CASE REPORT}

Three-year-old female child with episodes of recurrent vomiting since the first days of life under exclusive breastfeeding, and failure to thrive during the first months of life. The past history was unremarkable during pregnan- cy. The endocrine metabolic disease screening was negative at the 7th day of life. She had been under exclusive breastfeeding until one month and a half and started an infant formula at that time.

The investigation workup conducted by general pediatrician included: blood count, biochemistry, abdominal ultrasound, thyroid function tests, urinary culture, search for viruses in stools, which were all unremarkable.

Anti-reflux measures and a diet without CMP were proposed, with only limited adherence and a partial improvement in symptoms was noticed. At the age of II months an allergy study was carried out that revealed: IgE specific (slgE) to milk $23.8 \mathrm{kU}_{\mathrm{A}} / \mathrm{L}$; $n$ Bos $d 4$ a-lactalbumin $5.52 \mathrm{kU}_{\mathrm{A}} / \mathrm{L}$; $n$ Bos \& $5 \beta$-lactoglobulin $2.82 \mathrm{kU}_{\mathrm{A}} / \mathrm{L}$ and $n$ Bos $d 8$ casein $7.59 \mathrm{kU}_{\mathrm{A}} / \mathrm{L}$. An open OFC with milk was carried out, with peri-oral erythema 20 minutes after Iml of milk intake, confirming the diagnosis of CMPA. A diet without CMP was reinforced with improvement in weight and height and resolution of recurrent vomiting.

After the OFC that confirmed the diagnosis of CMPA, several inadvertent ingestions of milk and products containing milk occurred, despite the counseling given on avoidance measures. The introduction of beef occurred around the 6th month of age, with 2-3 ingestions per week. At the age of 7 months, minutes after ingestion of a soup with beef, the mother noticed appearance of facial erythema, palpebral and lip angioedema and irritability and, at 
Table I. Values of specific IgE along the course of the disease

\begin{tabular}{|c|c|c|c|}
\hline Specific IgE (kUA/L) & $\begin{array}{l}\text { Year } \\
2015\end{array}$ & $\begin{array}{l}\text { Year } \\
2017\end{array}$ & $\begin{array}{l}\text { Year } \\
2018\end{array}$ \\
\hline Milk & 23,8 & - & 18,9 \\
\hline nBos d 4 a-lactalbumin & 5,52 & 12,80 & 5,08 \\
\hline nBos d $5 \beta$-lactoglobulin & 2,82 & 3,7 & 0,91 \\
\hline nBos d 8 casein & 7,59 & 16,4 & 4,66 \\
\hline Beef & - & - & 6,66 \\
\hline Pork & - & - & $\mathrm{I}, 2 \mathrm{I}$ \\
\hline \multicolumn{4}{|l|}{ Skin Prick Tests* } \\
\hline Histamine & - & - & $6 \mathrm{~mm}$ \\
\hline Cow's milk & - & - & $10 \mathrm{~mm}$ \\
\hline nBos d 4 a-lactalbumin & - & - & $4 \mathrm{~mm}$ \\
\hline nBos d $5 \beta$-lactoglobulin & - & - & $4 \mathrm{~mm}$ \\
\hline$n$ Bos d 8 casein & - & - & $6 \mathrm{~mm}$ \\
\hline Beef & - & - & N/A \\
\hline Pork & - & - & $0 \mathrm{~mm}$ \\
\hline Chicken's meat & - & - & $0 \mathrm{~mm}$ \\
\hline
\end{tabular}

* Commercial extracts, Leti ${ }^{\circledR}$, Madrid, Spain; N/A, Not available.

the age of 2 years an episode of syncope minutes after the ingestion of beef was reported. A few more episodes of less severity occurred and, in those, mother couldn't exclude any contact with milk or products containing milk and did not administer any medication or searched for medical care. Possible allergic reactions in relation to beef were not suspected by the family, since the episodes did not occur with most beef ingestions and some of them occurred with possible, but uncertain milk contamination. She had never ingested pork.

Skin prick tests (commercial extracts, Leti ${ }^{\circledR}$, Madrid, Spain) were positive for milk extract and milk proteins (nBos d $4 \alpha$-lactalbumin, nBos d 5 -lactoblobulin, nBos d 8 casein) and negative for chicken and pork (clinical criteria for positivity $>3 \mathrm{~mm}$ comparing to negative control; commercial extracts for beef were not available).

Specific IgEs were positive to milk, $n B$ os $d 4$ a-lactalbumin, $n$ Bos $d 5 \beta$-lactoblobulin, $n$ Bos $d 8$ casein, cow's, pork (Table I) and $n$ Bos $d 6$ (Table 2).

An OFC with well-cooked beef (steamed for 20 minutes at $100^{\circ} \mathrm{C}$ ) was performed and was negative until a total of $30 \mathrm{gr}$. An OFC with medium rare beef (fried 4 minutes at $45^{\circ} \mathrm{C}$ ) was performed and was positive within 10 minutes after ingestion of approximately $5 \mathrm{gr}$, with appearance of lip edema, peri-labial erythema and local pruritus.

In order to determine if Bos $d 6$ could be the relevant allergen we performed an inhibition assay, briefly $150 \mu \mathrm{l}$ of patient serum was incubated overnight with one sponge of ImmunoCAP e204 (nBos d 6), the next day we recovered the serum inhibited and performed ImmunoCAP with the patient serum and the patient serum inhibited.

Percentages of inhibition were calculated with the formula (I- (slgE inhibited/slgE control) *I00) (Table 2).

Table 2. ImmunoCAP ${ }^{\circledR}$ and ImmunoCAP inhibition

\begin{tabular}{|c|c|}
\hline ImmunoCAP ${ }^{\circledR}\left(\mathbf{k} \mathbf{U}_{A} / \mathbf{l}\right)$ & $\begin{array}{l}\text { - } \text { Milk IgE (f2) } 19.0 \\
\text { - Beef IgE (f27) } 7.87 \\
\text { - Pork IgE (f26) I.27 } \\
\text { - } \operatorname{lgE} \text { nBos d } 6 \text { (e204) } 9.92 \\
\text { - IgE nSus s PSA (pork PSA) (e222) I.45 }\end{array}$ \\
\hline $\begin{array}{l}\text { InmunoCAP IgE inhibited with } \\
\text { "sponge" e204 (nBos d 6) }\end{array}$ & $\begin{array}{l}\text { - } \text { Milk IgE (f2) I } 2.4 \mathrm{kUA} / \mathrm{I}(35 \% \text { inhibition) } \\
\text { - } \text { Beef IgE (f27) } 2.8 \mathrm{kUA} / \mathrm{l}(64 \% \text { inhibition) } \\
\text { - Pork IgE (f26) } 0.54 \mathrm{kUA} / \mathrm{I}(57 \% \text { inhibition) } \\
\text { - IgE nBos d } 6 \text { (e204) } 3.54 \mathrm{kUA} / \mathrm{l}(64 \% \text { inhibition) } \\
\text { - IgE nSus s PSA (pork PSA) (e222) } 0.75 \mathrm{kUA} / \mathrm{l}(48 \% \text { inhibition) }\end{array}$ \\
\hline
\end{tabular}

Bos d 4 - $\alpha$-lactoalbumin; Bos d 5 - $\beta$-lactoglobulin; nBos d 6 - Bovine serum albumin; Bos d 8 - Casein 
Some of the described episodes were considered as probable anaphylaxis, according to clinical criteria and a self-injector of epinephrine (I50 mcg) was prescribed, along with avoidance of the implicated foods, dietary advice, anti-histamine and oral corticosteroid for mild reactions.

\section{DISCUSSION}

Immunological mechanisms associated with meat allergy can be IgE or non-IgE mediated. Clinically, three main forms of IgE-mediated meat allergy are now recognized: primary meat allergy, pork-cat syndrome and alphagal syndrome 6,7 .

The list of allergens associated with meat allergy includes proteins and some carbohydrates. Serum proteins and immunoglobulins seem to be the primary allergens of beef and meat from other mammals ${ }^{6,7}$. Serum albumin has been described as implicated in cow, pork, rabbit, lamb and chicken's meat allergy ${ }^{7,8}$. Three major allergens (Bos $d$ 6, Bos $d 7, \alpha-g a l$ ) are already identified as main causative agents implicated in bovine meat allergy ${ }^{7}$.

The existence of cross-reactivity between beef and cow's milk has been attributed to serum albumin and gamma-immunoglobulins. The low reported prevalence of meat allergy may be partially explained by the thermal lability of serum albumin and the fact that most of the meat is ingested in the cooked form ${ }^{5}$.

In our case, sensitization to Bos $d 6$ explains meat allergy, which can be showed by the inhibition that Bos $d$ 6 achieves in beef and pork IgE in ImmunoCAP.

The clinical presentation of a beef allergy in children is challenging as the symptoms in the first years of life can be unspecific; the presence of other food allergies, such as CMPA, may be a confounding variable and the presence of symptoms is dependent on the cooking and processing status. Since Bos $d 6$ is a heat labile protein, the process of cooking beef may be, in some cases, insufficient to have an effect on the complex matrix of meat and the associated serum albumins. The performance of two OFC, with well-cooked and medium-rare meat, is of great interest given that the results can be absolutely different, as the effect of cooking in meat allergy is already known. The authors consider that this strategy is of utmost importance since that a tolerance to well-cooked meat may assure a meat intake in a child with diet deficiencies, and OFC with rare meat allows to discard meat allergy. Considering tolerance to other mammalian meat, such as pork or lamb, there has been little research into whether children allergic to beef can tolerate it or not, however, considering the high degree of homology between mammalian albumins it is suggested that there is significant risk of lgE cross-reactivity between these species ${ }^{8}$.

Considering the early diagnosis, the resolution of the symptoms within the first years of life is expected. Since meat is an important source of protein, challenging in order to evaluate development of tolerance is advisable. After exposing to parents all our concerns regarding diet deficiencies, risk of reactions and expectations on development of tolerance, parents preferred waiting to introduce meat until tolerance to medium-rare meat was achieved and proved with OFC.

\section{Conflito de interesses}

Os autores declaram que não existem conflitos de interesses.

\section{ORCID:}

Maria Luís Marques (iD 0000-0003-224I-7889

Inês Falcão iD 0000-0002-4783-2539

Moisés Labrador-Horrillo (iD) 0000-0003-3222-2380

Helena Falcão (iD) 0000-0002-4503-4I38

Leonor Cunha (iD) 0000-0002-3680-3687

Autor correpondente:

Maria Luís Marques

Centro Hospitalar Universitário do Porto

Largo Prof. Abel Salazar

4099-00I - Porto, Portugal

Email: maluis234@gmail.com 


\section{REFERÊNCIAS}

I. Crespo JF, Pascual C, Burks AW, Helm RM, Esteban MM. Frequency of food allergy in a pediatric population from Spain. Pediatr Allergy Immunol 1995;6:39-43. doi: I0.1 III/j.1399-3038.1995. tb00256.x.

2. Steinke M, Fiocchi A, Kirchlechner V, Ballmer-Weber B, Brockow $\mathrm{K}$, Hischenhuber $\mathrm{C}$, et al. Perceived Food Allergy in Children in 10 European Nations. Int Arch Allergy Immunol 2007; 143:290-5. doi:10.1159/000100575.

3. Martelli A, De Chiara A, Corvo M, Restani P, Fiocchi A. Beef allergy in children with cow's milk allergy; cow's milk allergy in children with beef allergy. Ann Allergy Asthma Immunol 2002; 89:38-43. doi:10.1016/S108I-1206(10)6212I-7.
4. Sampson HA. Food hypersensitivity as a pathogenic factor in atopic dermatitis. N Engl Reg Allergy Proc 1986;7:5II-9. doi: I0.2500/I08854I867790454I2.

5. Werfel S, Cooke S, Sampson H. Clinical reactivity to beef in children allergic to cow's milk. J Allergy Clin Immunol 1997;99:293300. doi:10.1016/S0091-6749(97)70045-9.

6. Wilson JM, Platts-Mills TAE. Red meat allergy in children and adults: Curr Opin Allergy Clin Immunol 2019;19:229-35. doi:10.1097/ ACl.0000000000000523.

7. Wilson JM, Platts-Mills TAE. Meat allergy and allergens. Mol Immunol. 2018;100:107-12. doi:10.1016/j.molimm.2018.03.018.

8. Chruszcz M, Mikolajczak K, Mank N, Majorek KA, Porebski PJ, Minor W. Serum albumins-unusual allergens. Biochim Biophys Acta 2013;1830:5375-8I. doi: 10.1016/j.bbagen.2013.06.016. 